\title{
MENTAL HEALTH AND MIGRATION IN MESOAMERICA: A SYSTEMATIC REVIEW
}

\section{Julio TORALES ${ }^{1}$, Iván BARRIOS ${ }^{2}$, Israel GONZÁLEZ ${ }^{3}$.}

${ }^{1}$ Researcher and Professor of Psychiatry and Medical Psychology, School of Medical Sciences, National University of Asunción, San Lorenzo - Paraguay.

${ }^{2}$ Teaching assistant, Research Methodology Department, School of Medical Sciences, National University of Asunción, San Lorenzo - Paraguay.

${ }^{3}$ Resident physician of Psychiatry, School of Medical Sciences, National University of Asunción, San Lorenzo - Paraguay.

How to cite this article: Torales J, Barrios I, González I. Mental Health and Migration in Mesoamerica: a systematic review. Medicina Clínica y Social. 2018;2(1):25-36.

\section{ABSTRACT}

Introduction: Millions of people live outside their country of origin, they are immigrants, refugees or exiled, each with their own history, their strengths and weaknesses; but they all have something in common: the fact that they must adapt culturally to the place where they now live, and they must be socially accepted in this new group. Objective: The main goal of this article was to perform a search and systematic review in order to find research in the fields of mental health and migration, providing a global view of the situation in Mesoamerica and showing the risk factors and the protective factors that influence the migratory process. Methodology: We performed a systematic review of the following databases: PubMed/MEDLINE and LILACS. We included publications from the last five years (2012 - 2017), in English and Spanish, if they were published in indexed journals and if the full text version was available. Results: We found that the most frequent mental disorders were related to stress, the distress generated by the separation from family members, the problems faced when crossing the border, and the conditions that motivate the migration. The most common diagnoses where generalized anxiety disorder, major depressive disorder, post-traumatic stress disorder, and substance use disorder. Conclusions: In Mesoamerica, there is a dearth of research exposing with clarity the current situation of migration and mental health and describing the details of the reality in each country. This is important because, besides from the personal features and support networks that these people have, a fundamental factor that determines their mental health in their new country is the country of origin: the living conditions in this country and the motives that force people to migrate.

Keywords: Psychological distress; Migrants; Migratory process; Mental health; Mental disorders.

\section{INTRODUCTION}

More than 200 million people live outside their country of origin, they are immigrants, refugees or exiled, each with their own history, their strengths and weaknesses; but they all have something in common: the fact that they must culturally adapt to the place where they live now, and, of course, they must be socially accepted in this new group (1).

It is known that an abrupt change in lifestyle will have repercussions in the health of the individual, many articles suggest that certain factors, such as health status before migration, age, sex, marital status, linguistic abilities, perceived discrimination, and duration of stay in the host country can generate a deterioration in the health status, that may have been optimal before the migration (2). 
Research performed in the United States show high levels of chronic stress in 21 to 34 percent of immigrants, making this a predisposing factor that can interfere in the mental health of this particular population (3-5).

In light of this, the main goal of this article will be to perform a search and systematic review in order to find research in the fields of mental health and migration, providing a global view of the situation in Mesoamerica and showing the risk factors and the protective factors that influence the migratory process. Likewise, we will search reports from NGOs and government organizations to analyze their conclusions and their ideas regarding this subject.

\section{METHODOLOGY}

We performed a systematic review of the literature in the PubMed/MEDLINE, LILACS, and CICCO databases using the syntax [(mental health) OR (mental illness) OR (mental disorders) OR (psychology) OR (psychiatry) OR (psychosocial) AND (migration) OR (immigrant) OR (migrant workers) AND (Mexico) OR (Belice) OR (Guatemala) OR (El Salvador) OR (Honduras) OR (Nicaragua) OR (Costa Rica) OR (Panamá) OR (Colombia) OR (República Dominicana)]. We limited our search to papers published in the last five years (2012 - 2017). The types of studies included were systematic reviews, case reports, clinical trials, comparative studies, evaluative studies, multicentric studies, case-control studies, observational studies, cohort studies, and metanalyses.

We included all the articles that were published in indexed scientific journals when a full text version was available either in English or Spanish. After classifying the studies, we recovered the articles in digital format to do a critical reading of the evidence, considering the inclusion criteria.

\section{RESULTS}

\section{Description of the studies}

After eliminating duplicates, we identified 16392 abstracts of unique studies in the databases. We screened the abstracts for inclusion in the study and exclude 16343. We studied the full text of the 49 remaining studies and finally included 39 studies (Figure 1).

\section{Belize}

Their mental health system is composed by two ambulatory mental health services, four psychiatric beds in a general hospital, and eight public general hospitals. In the last years, they have made progress in the mental health care thanks to the support from the Pan American Health Organization (PAHO), which has trained nurses in the field of psychiatry (6).

It is important for mental health professionals to be aware of the risks to which people in migrant communities are exposed. They suffer many kinds of mistreatments and present a wide range of symptoms, many of them secondary to bullying, these symptoms can include insomnia, nightmares, multiple physical symptoms, anxiety, mood instability, lack of concentration, psychosis, among others (7). 
Figure 1. Al Algorithm of studies included in the systematic review

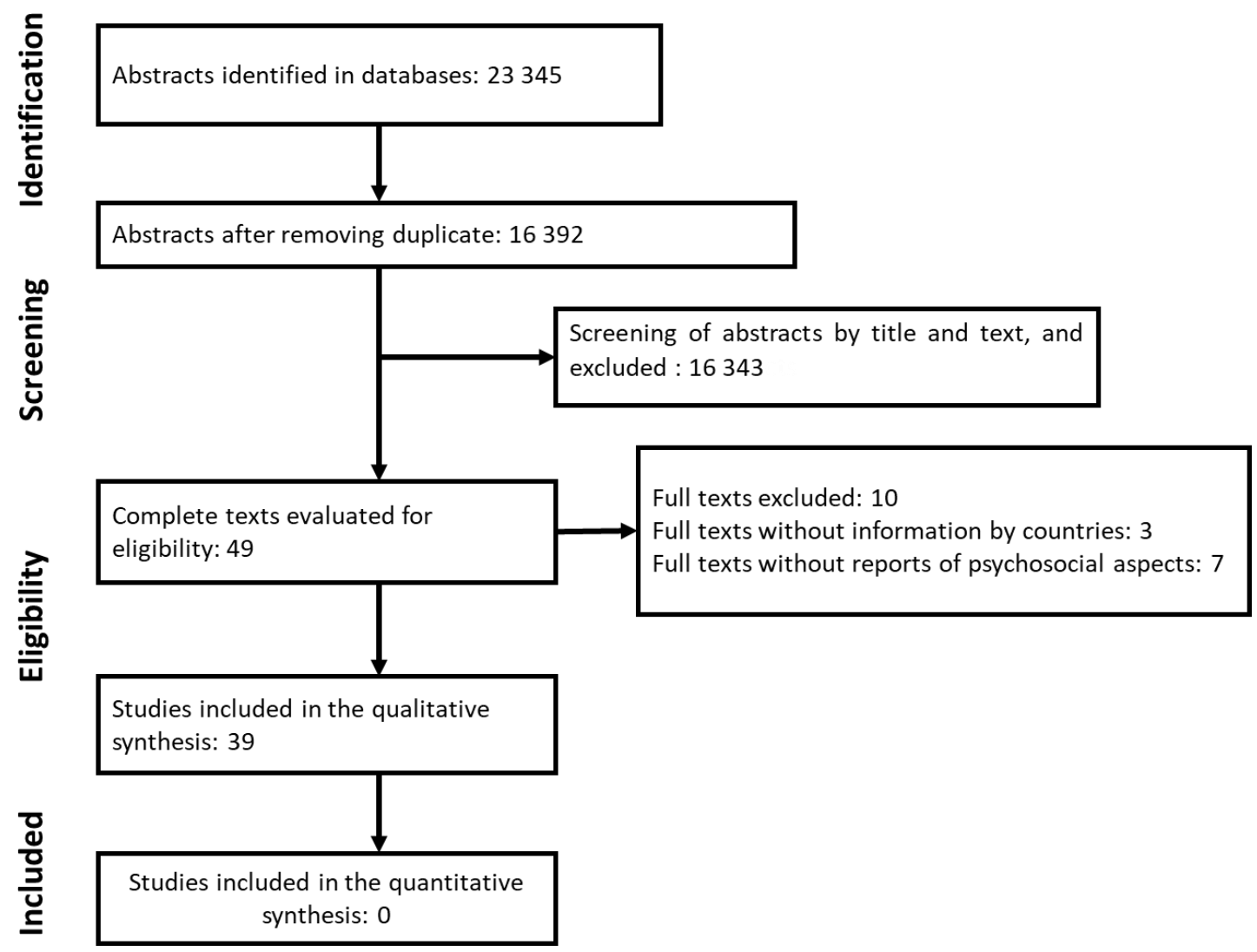

\section{Colombia}

The main hosts for Colombian migration are Venezuela, the United States, and Spain (8). The main problems detected in Spain are those related to parental migration in children and the caretakers, which is why this country has tried to provide help to the issues presented by transnational families according to their migratory situation (8). The satisfaction in daily life is negatively associated with the perceived group prejudice and with the perceived personal discrimination; it is positively associated with perceived material wellbeing. Regarding self-esteem, it is also negatively associated with perceived group prejudice and personal discrimination (9).

Colombian migrants experience a higher risk of having poor mental health when they lose their jobs, when the working hours increase, and when their wages are low or diminished. On the other hand, attaining social security registration has been identified as a protective factor in the mental health of this population $(10,11)$.

Self-esteem is an important predictor of wellbeing in migrants in the United States of America because they show high levels of wellbeing as their self-esteem increases (12). The Colombian migrants in this country reported that the biggest hinderer for access to health care services are economic barriers; also, $13 \%$ of Spanish migrants to the United States reported being diagnosed with depression at some point in their lives, and $40 \%$ reported having a family member diagnosed with this disorder (13). 
The sources of stress due to acculturation with larger capacity for predicting mental health outcomes are distance from the country of origin, difficulties in social relationships with other migrants, and perceived discrimination and rejection. In this context, $22.1 \%$ of Colombian migrants in Chile show symptoms of depression and anxiety, and $78.5 \%$ show difficulties in social adjustment (14). Regarding forced migration, Colombia has usually ranked very high due to decades of conflicts associated to drug traffic. The stress factors resulting from these situations are augmented with the ones caused by the loss of the home, increasing the probability of developing psychopathological outcomes including major depression, PTSD, generalized anxiety disorders, somatic symptoms disorders, and increased use of alcohol and illicit drugs (15).

\section{Costa Rica}

Costa Rica has an important population of international migrants, composed mainly by Nicaraguans. According to the census of 2000 , Nicaraguans constitute approximately $6 \%$ of the Costa Rican population. Many of these migrants are women of fertile age, which increases the birth rate in this country, but this vulnerable population has poor access to general health and reproductive health services. Other aspects are presented in the section corresponding to Nicaragua (16).

\section{El Salvador, Honduras, and Guatemala}

After Mexicans, migrants from El Salvador, Guatemala, and Honduras (approximately 1.56 million in 2010) constitute the largest population of unauthorized immigrants in the United States of America. The main motive for their migration is the political instability and the high levels of violence in their country of origin. It is worth noting that the context of the migration of Salvadorans who go through Mexico is full of episodes of violence and human rights violations (17).

In the last years, there has been an increase in the migration of unaccompanied minors to the US, coming from El Salvador, Honduras, and Guatemala, motivated by the lack of development opportunities, the increase in violent crimes, and the desire to be reunited with their families (18). During their migratory journey, these minors have a higher risk of experiencing traumatic events due to the mistreatment by the contrabandists, and of being caught by people traffickers (19).

$32 \%$ of migrants report that they have at least one family member that was murdered; this rises the rates of PTSD and depression in migrants coming from El Salvador (32\%), Honduras (34\%), and Guatemala (30\%) (5).

A study used screening tests for different mental disorders in the migrant population from these countries and found that $53 \%$ of them suffer from at least one psychiatric disorders, with major depression being the most frequently diagnosed disorder (22\%), followed by alcohol dependence (13\%), panic disorder (12\%), and alcohol abuse (11\%) (20).

Married migrants, as opposed to non-married ones, have lower probabilities of suffering from alcohol dependence. On the contrary, three factors (number of attempts to travel, experiences of abuse, and lack of family or friends in the destination country) are associated with 
higher probabilities of developing alcohol dependence: for example, probabilities of dependence increase $47 \%$ with each additional attempt to travel $(20,21)$.

Sexual workers are victims of abuse and violence due to the "double vulnerability" that they experience under their conditions of non-citizens and sexual workers (22).

\section{México}

$26 \%$ of Mexican migrants live below the poverty level and between 56 and $70 \%$ do not have health insurance (23).

The high levels of violence and delinquency in Mexico as a consequence of drug traffic have been associated with the rise of migration patterns to the United States. For this population, the traumatic experiences start during the transit to the new country, since the policies in the border between the US and Mexico make the process of migration very dangerous, and conductive to dehydration and, in extreme cases, death. All these traumatic experiences increase the mental health problems including PTSD, depression, substance abuse, and other risky behavior (24).

The physical and psychological difficulties that migrants from Mexico experience are due to the structural vulnerability, defined as the inequality resulting from political, economic, and material marginalization that contributes to oppression through discrimination due to gender, ethnicity and class (25).

33.6\% of Mexican migrants increased their alcohol intake after migrating. $37.7 \%$ has increased their tobacco intake, and $46.3 \%$ used illicit drugs for the first time in the United States of America. The most frequently consumed drugs are marijuana (19\%), cocaine (12.6\%), and crack (5\%) (26).

The risk factors for drug use in the Mexican migrant population are alcohol intake, being friends with drug users, migratory stress, and arriving to the country of destiny. On the contrary, the use of coping strategies and knowledge of the English language are protective elements for substance use in this population (26).

Migrants usually associate depression with the separation from their loved ones due to deportation or detention; at the same time, health care professionals detected the presence of depression and anxiety in relation to economic stress, fear of detention, family separation, and social isolation (27).

In general, $46 \%$ of Mexican migrants reported depressive symptoms in the range of clinical preoccupation. The best predictors of depression in this population are separation from their families, sending remittances to Mexico, fear and preoccupation with confrontations with the police, the treatment received from non-Hispanics, and lack of support (28).

Among deported Mexican migrant, common mental disorders have a prevalence of $16 \%$. According to this report, females sex, the number of people living in the same house, having a spouse or a partner in the United States of America, the number returns to Mexico, and the anxiety as a personality trait were directly associated with a higher number of disorders; social support was a protective factor $(29,30)$. 
Indigenous Mexicans make up the greatest proportion of migrants from Mexico to the United States, and they are vulnerable to discrimination at work, to disparities in the healthcare provided to them, and to the development of hazardous use of alcohol associated with migration (31).

Some migrants return to Mexico due to mental health crises precipitated by conditions of structural vulnerability and "illegality" in the United States of America. Once there, they have to fight to interpret and dissipate what has been called "transnational disorders": disorders that are structurally produced and experience within the frontiers of one's own country (32).

Nicaragua

Nicaraguan migrants travel mainly to two destinies: $55 \%$ travel to Costa Rica, and $36 \%$ to the United States. 9\% go to a variety of destinies, mainly Canada, Guatemala, El Salvador and Honduras (33).

These are populations that are vulnerable to poverty, discrimination and social isolation. More than half of them are young people of 15 to 34 years of age, they have a twofold risk of dying as a consequence of homicides than their Costa Rican counterparts, suicide is also highly prevalent in this population, with a prevalence of $9.3 \%$. Poverty, the composition of the population, and the economic activities are variables that more accurately explain the rate of homicide in young Nicaraguans $(34,35)$.

The sectors in which they work include mainly construction, agriculture, and domestic work (36). Because of the migration of women, the children stay with their grandmothers, who suffer the emotional anguish of having to take care of their grandchildren and are preoccupied with the uncertainty surrounding migration, remittances, and the lost of the unity and solidarity of the family life (37).

The main identified intrapersonal barriers are the lack of confidence and low self-esteem, with a negative attitude towards recreation, nostalgia about family, fear of going out and of becoming victims of assault (38).

\section{Panama}

There has been an increase in the migrant population in this country. According to a census in $2010,49 \%$ of women and $50 \%$ of men in this country are migrants. Women migrants report harassment and abuse as factors that affect their mental health, with feelings of loneliness, anxiety, and depressive states; however, many of them don't see these factors as requiring assistance from a professional (39).

There are many Colombian women from 25 to 42 years old who work there as sexual workers. While they suffer violence as a consequence of their line of work, most of the violence episodes involve their partners or the police. Most of them send remittances to their country of origin and, in $65 \%$ of the cases, they are used to maintain their children back home, $90 \%$ of them reported that financial needs are the main motivator for getting involve in sex work. 
Dominican Republic

A great number of mothers from this country decide to migrate to the United States, Spain, and Canada. 52\% of Dominican immigrants in the United States and 64\% in Spain are women, at least 1 child per woman migrant stays in the Dominican Republic. From the viewpoint of the psychological development, the absence of parents due to migration is one of the most stressful factors that affect health status, education, psychological wellbeing, and social conduct of the children staying in the country of origin (40).

The most studied risk factors for the child before the migration are a hasty and unplanned designation of a caretaker, and an incorrect and untimely way of informing the child about the decision to migrate. The protective factors before the migration are a good planification and the agreements about the education of the child, trust in the correct use of the remittances, and adequate providing of information about the decision to the child, including psychological preparation and the use of reasons that do not imply guilt on the part of the child (41).

The high levels of distress, depression, and anxiety can be explained by the exposure to stress factors such as discrimination and low socioeconomic status, as well as the exhaustion of the protective resources such as ethnic and familiar identity. The years spent in the United States were also associated with poor mental health outcomes. This can lead to an increase in the use of substances, Dominican men are more propense to using smoking if they are immigrants (42).

In the Dominican Republic there is a large number of Haitian migrants who report systematic humiliation as a reason of mental anguish and a barrier to their health care. However, Dominicans mention that discrimination is not a current social problem and attribute negative social interactions to socio-cultural, behavioral and biological differences between Dominicans and Haitians (43).

The depression, anxiety and mental distress present in Haitian migrants are associated with negative social interactions (interrogation or deportation, mistreatment), lack of social support and unsatisfied social needs (44).

\section{DISCUSIÓN}

A migrant can be defined as the person who moves from one place to another to live, and generally work, either temporarily or permanently. Migrants who have gone through situations of violence or torture are more likely to have certain psychological symptoms such as anxiety, overexcitement, loss and grief, guilt and shame, intrusions, evasion and discouragement (45).

Age, gender, motive of migration, and the education of people characterize the "personality" factor; support, adaptation, and mourning for loss characterize the "experiences". Lastly, having social support and a healthy network of contacts and cultural identity are related to the "cultural shock" (45).

The Ulysses syndrome or immigrant syndrome with chronic and multiple stress is a reactive syndrome of stress in situations of extreme migratory grief; it is not a disease per se but is 
located in the field of mental health that is broader than the scope of pure psychopathology (46). The main mental health problems found in the migrant population are anxiety, depression, substance abuse and dependence, post-traumatic stress disorder, suicide and suicide attempt (47).

As for depression, being a woman, a deficient social network, economic insecurity and traumatic episodes are related and can be considered as risk factors for suffering from depression. While the factors that can be considered as protective against anxious and depressive symptoms are the level of education and support networks (family, friends) (48).

Distinctions in racial or ethnic treatment, racial problems in the neighborhood, expressions of discomfort or anger, or barriers in health care, are related to depressive symptoms. Again, social and family support are protective factors in these cases (2).

Being male, young, single, and of low sociocultural level are considered as risk factors for the consumption of alcohol and drugs. Being Latin American is a risk factor for alcohol consumption and unemployment increases the odds of consuming. A notable fact is that immigrants who consume alcohol and drugs show high levels of deterioration, both in dependence and abuse of alcohol and drugs, as well as in psychiatric comorbidities (49).

Migrants have higher rates of suicide than the general population and this is associated with factors related to age, sex, country of birth; Likewise, first-generation migrants have a lower risk of suicide than second-generation migrants, who in turn have a lower risk of suicide than third-generation migrants. The above can be explained by the process of assimilation (50).

Social support is the main long-term protective factor against mental disorders, so it is questionable that recipient countries do not include migrants in different recreational activities of a social and cultural nature $(38,45)$.

Migrants are vulnerable to develop mental disorders throughout the process of migration, where some characteristics of the country of origin, the individual, the circumstances of migration, the host country and the assimilation and acculturation processes constitute important phenomena for the deterioration of mental health. The countries must not only propose medical or psychotherapeutic treatments for them, but they must also implement public health policies and strategies that defend and promote human rights, which are often violated, especially in those migrants who are victims of violence and torture or are forced to migrate. At the same time, we must think about the consequences that this brings, not only to those who migrate, but to those who remain in the country of origin, who suffer the absence of the loved one, and also in the consequences it brings to the place of reception, which must adapt and contribute so that there is a correct and healthy process of assimilation.

We can conclude, then, that migration constitutes a public health problem in Mesoamerica, for which countries must implement public policies that ensure access to health, as well as promote correct insertion. More research is needed in this aspect, since one of the main limitations of the research was the scarce research on the subject in Mesoamerica that allows an in-depth study and perform a meta-analysis to obtain results of greater impact. 


\section{CONFLICTS OF INTEREST AND FUNDING}

Conflicts of interest: none. Funding source: none.

\section{REFERENCES}

1. Bas-Sarmiento $P$, Saucedo-Moreno MJ, Fernández-Gutiérrez M, Poza-Méndez $M$. Mental Health in Immigrants Versus Native Population: A Systematic Review of the Literature. Arch Psychiatr Nurs. 2017;31(1):111-121. https://doi.org/10.1016/j.apnu.2016.07.014

2. Jurado D, Alarcón RD, Martínez-Ortega JM, Mendieta-Marichal Y, Gutiérrez-Rojas L, Gurpegui M. Factores asociados a malestar psicológico o trastornos mentales comunes en poblaciones migrantes a lo largo del mundo. Rev Psiquiatr Salud Ment. 2017;10(1):45-58. https://doi.org/10.1016/j.rpsm.2016.04.004

3. Pozos-Radillo BE, Aguilera-Velasco M, Acosta-Fernández M, Pando-Moreno M. Perfil de estrés y estrés crónico en migrantes mexicanos en Canadá. Rev Salud Pública. 2014;16(1):63-75. http://dx.doi.org/10.15446/rsap.v16n1.35812

4. Horyniak D, Melo JS, Farrell RM, Ojeda VD, Strathdee SA. Epidemiology of Substance Use among Forced Migrants: A Global Systematic Review. PLoS ONE. 2016;11(7):1-34. https://doi.org/10.1371/journal.pone.0159134

5. Keller A, Joscelyne A, Granski M, Rosenfeld B. Pre-Migration Trauma Exposure and Mental Health Functioning among Central American Migrants Arriving at the US Border. PLoS ONE. 2017;12(1):1-11. https://doi.org/10.1371/journal.pone.0168692

6. Razzouk D, Gregorio G, Antunes R, Mari JDJ. Lessons learned in developing community mental health care in Latin American and Caribbean countries. World Psychiatry. 2012;11(3):191-195. https://doi.org/10.1002/i.20515545.2012.tb00130.x

7. Srabstein JC. The Global Implications of Bullying and Other Forms of Maltreatment, in the Context of Migratory Trends and Psychiatric Resources. Child Adolesc Psychiatr Clin N Am. 2015;24(4):799-810. https://doi.org/10.1016/j.chc.2015.06.008

8. Martínez R, Clara M. Inmigración y salud psicosocial: creando puntes, formando redes. Rev Castell-Manchega Cienc Soc. 2012;(13):253-73. https://doi.org/10.20932/barataria.v0i13.126

9. Murillo Muñoz J, Molero Alonso F. Factores psicosociales asociados al bienestar de inmigrantes de origen colombiano en España. Psychosoc Interv. 2012;21(3):31929. http://dx.doi.org/10.5093/in2012a28

10. Murillo Muñoz J, Molero Alonso F. Relación entre la Satisfacción Vital y otras Variables Psicosociales de Migrantes Colombianos en Estados Unidos. Rev Colomb Psicol. 2016;25(1):15-32.

11. Robert G, Martínez JM, García AM, Benavides FG, Ronda E. From the boom to the crisis: changes in employment conditions of immigrants in Spain and their effects on mental health. Eur J Public Health. 2014;24(3):404-9.

12. Madrigal C. Colombians in the United States: A Study of Their Well-Being. Adv Soc Work. 2013;14(1):26-48.

13. Martinez Tyson D, Arriola NB, Corvin J. Perceptions of Depression and Access to Mental Health Care Among Latino Immigrants: Looking Beyond One Size Fits All. Qual Health Res. 2016;26(9):1289-302. 
14. Urzúa M A, Heredia B O, Caqueo-Urízar A. Salud mental y estrés por aculturación en inmigrantes sudamericanos en el norte de Chile. Rev Médica Chile. 2016;144(5):563-70.

15. Shultz JM, Garfin DR, Espinel Z, Araya R, Oquendo MA, Wainberg ML, et al. Internally Displaced "Victims of Armed Conflict" in Colombia: The Trajectory and Trauma Signature of Forced Migration. Curr Psychiatry Rep. 2014;16(10):475.

16. Sintonen H, Bonilla-Carrión RE, Ashorn P. Nicaraguan migration and the prevalence of adolescent childbearing in Costa Rica. J Immigr Minor Health. 2013;15(1):1118.

17. Gómez-Johnson C. De la migración económica a la migración forzada por el incremento de la violencia en El Salvador y México. Estud Políticos. 2015;(47):199-220.

18. Soto-Acosta W, Morales-Camacho MF. La migración de niños y niñas de Centroamérica hacia los Estados Unidos: amenaza emergente transnacional. Temas Nuestra América Rev Estud Latinoaméricanos. 2016;31(58):55-73.

19. Estefan LF, Ports KA, Hipp T. Unaccompanied Children Migrating from Central America: Public Health Implications for Violence Prevention and Intervention. Curr Trauma Rep. 2017;3(2):97-103.

20. Daniel-Ulloa J, Reboussin BA, Gilbert PA, Mann L, Alonzo J, Downs M, et al. Predictors of Heavy Episodic Drinking and Weekly Drunkenness Among Immigrant Latinos in North Carolina. Am J Mens Health. 2014;8(4):339-48.

21. López Pozos C. Veredas inciertas, destinos cruzados. Migración femenina de Honduras y su paso por México. Visioni Latinoam. 2015;(13):7-32.

22. Rocha-Jiménez T, Brouwer KC, Silverman JG, Morales-Miranda S, Goldenberg SM. Migration, violence, and safety among migrant sex workers: a qualitative study in two Guatemalan communities. Cult Health Sex. 2016;18(9):965-79.

23. Juárez-Ramírez C, Márquez-Serrano M, Salgado de Snyder N, Pelcastre-Villafuerte $\mathrm{BE}$, Ruelas-González MG, Reyes-Morales $\mathrm{H}$. La desigualdad en salud de grupos vulnerables de México: adultos mayores, indígenas y migrantes. Rev Panam Salud Publica. 2014;35(4):284-90.

24. Salas LM, Ayón C, Gurrola M. Estamos Traumados: The Effect of Anti-Immigrant Sentiment and Policies on the Mental Health of Mexican Immigrant Families. J Community Psychol. 2013;41(8):1005-20.

25. Valdez ES, Valdez LA, Sabo S. Structural Vulnerability Among Migrating Women and Children Fleeing Central America and Mexico: The Public Health Impact of "Humanitarian Parole". Front Public Health. 2015;3:163.

26. Hernández A, Luis J, Hernández A, Luis J. Consumo de drogas y respuestas al estrés migratorio entre los migrantes mexicanos que se dirigen a Estados Unidos. Front Norte. 2016;28(56):113-33.

27. Crocker R. Emotional Testimonies: An Ethnographic Study of Emotional Suffering Related to Migration from Mexico to Arizona. Front Public Health. 2015;3:177.

28. Letiecq BL, Grzywacz JG, Gray KM, Eudave YM. Depression among Mexican men on the migration frontier: the role of family separation and other structural and situational stressors. J Immigr Minor Health. 2014;16(6):1193-200.

29. Borges G, Zamora B, García J, Orozco R, Cherpitel CJ, Zemore SE, et al. Symptoms of anxiety on both sides of the US-Mexico border: The role of immigration. J Psychiatr Res. 2015;61:46-51. 
30. Bojorquez I, Aguilera RM, Ramírez J, Cerecero D, Mejía S. Common Mental Disorders at the Time of Deportation: A Survey at the Mexico-United States Border. J Immigr Minor Health. 2015;17(6):1732-8.

31. Zúñiga ML, Lewin Fischer P, Cornelius D, Cornelius W, Goldenberg S, Keyes D. A transnational approach to understanding indicators of mental health, alcohol use and reproductive health among indigenous mexican migrants. J Immigr Minor Health. 2014;16(3):329-39.

32. Duncan WL. Transnational Disorders: Returned Migrants at Oaxaca's Psychiatric Hospital. Med Anthropol Q. 2015;29(1):24-41.

33. Hobbs AW, Jameson KP. Measuring the effect of bi-directional migration remittances on poverty and inequality in Nicaragua. Appl Econ. 2012;44(19):2451-60.

34. Bonilla RE. Uso de un modelo log-lineal de Poisson para el estudio de los homicidios contra jóvenes inmigrantes nicaragüenses en Costa Rica. Poblac Salud En Mesoamérica. 2017;14(2):1-14.

35. Bonilla RE, Chavarría JB. Mortalidad de inmigrantes nicaragüences jóvenes en Costa Rica. Enfermedades versus causas externas. Poblac Salud En Mesoamérica. 2015;13(1):117-29.

36. Hidalgo A. El acceso a la justicia laboral de las personas trabajadoras migrantes nicaragüenses en Costa Rica. Relac Laborales Derecho Empl. 2016;4(3):1-18.

37. Yarris KE. "Pensando mucho" ("thinking too much"): embodied distress among grandmothers in Nicaraguan transnational families. Cult Med Psychiatry. 2014;38(3):473-98.

38. Salazar-Salas CG. Inmigrantes nicaragüenses en Costa Rica: barreras y estrategias de negociación para recrearse. Actual Investig En Educ. 2013;13(1):142-81.

39. Corina L. Violencia y trabajo sexual remunerado; el caso de las migrantes colombianas en Panamá. Rev Soc Humanist. 2015;17(2):95-116.

40. Uriarte Arciniega J de D. Social Perception of Risk and Protection Factors for the Children of Emigrant Mothers: A Study in the Dominican Republic. Migr Int. 2011;6(2):101-32.

41. Perreira KM, Gotman N, Isasi CR, Arguelles W, Castañeda SF, Daviglus ML, et al. Mental Health and Exposure to the United States: Key Correlates from the Hispanic Community Health Study of Latinos. J Nerv Ment Dis. 2015;203(9):670-8.

42. Riosmena F, Kuhn R, Jochem WC. Explaining the Immigrant Health Advantage: Selfselection and Protection in Health-Related Factors Among Five Major NationalOrigin Immigrant Groups in the United States. Demography. 2017;54(1):175-200.

43. Keys HM, Kaiser BN, Foster JW, Minaya RYB, Kohrt BA. Perceived discrimination, humiliation, and mental health: a mixed-methods study among Haitian migrants in the Dominican Republic. Ethn Health. 2015;20(3):219-40.

44. Kaiser BN, Keys HM, Foster J, Kohrt BA. Social stressors, social support, and mental health among Haitian migrants in the Dominican Republic. Rev Panam Salud Publica. 2015;38(2):157-62.

45. Martínez-Viciana C. Respondiendo a las necesidades de salud mental de los migrantes. Médicos sin Fronteras; 2012.

46. Achotegui J. Emigrar hoy en situaciones extremas. El síndrome de Ulisis. Rev Psicol. 2012;30(2):79-86. URL. 
47. Patterson B, Kyu H, Georgiades K. Age at Immigration to Canada and the Occurrence of Mood, Anxiety, and Substance Use Disorders. Can J Psychiatry. 2012;57(4):210-217. https://doi.org/10.1177/070674371305800406

48. Tinghög P, Al-Saffar S, Carstensen J, Nordenfelt L. The Association of Immigrantand Non-Immigrant-Specific Factors With Mental III Health Among Immigrants in Sweden. Int J Soc Psychiatry. 2010;56(1):74-93. https://doi.org/10.1177/0020764008096163

49. Qureshi A, Garcia Campayo J, Eiroa-Orosa FJ, Sobradiel N, Collazos F, Febrel Bordejé $\mathrm{M}$, et al. Epidemiology of substance abuse among migrants compared to native born population in primary care. Am J Addict. 2014;23(4):337-342. https://doi.org/10.1111/j.1521-0391.2013.12103.x

50. Patel K, Kouvonen A, Close C, Väänänen A, O'Reilly D, Donnelly M. What do register-based studies tell us about migrant mental health? A scoping review. Syst Rev. 2017;6(1):78. https://doi.org/10.1186/s13643-017-0463-1 